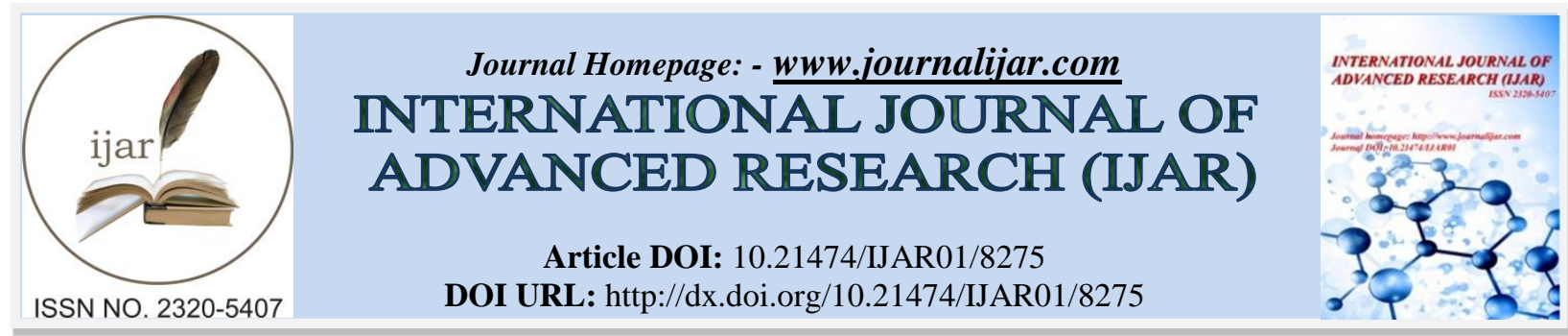

RESEARCH ARTICLE

\title{
COMPARISON OF CELISA AND BLOOD SMEARS TO ASSESS ANAPLASMA SPP INCIDENCE IN DWARF GOATS FROM BÉOUMI (CÔTE D'IVOIRE).
}

\author{
Oussou k. A. And karamoko y. \\ Animal biology and cytology Laboratory, UFR SN, Nangui Abrogoua University, Abidjan (Côte d'Ivoire), 02 BP \\ 801 Abidjan 02.
}

\section{Manuscript Info}

Manuscript History

Received: 20 October 2018

Final Accepted: 22 November 2018

Published: December 2018

\section{Keywords:}

Anaplasma spp, cELISA, Blood smears, Prevalence, Agreement.

\section{Abstract}

A study of dwarf goats in Béoumi (Côte d'Ivoire) aimed to compare two diagnostic techniques in the fight against Anaplasma spp. The competitive immunoenzymatic technique (cELISA) and technique of direct observation of blood smears with optical microscope. A total of 540 blood samples were taken from 270 apparently healthy dwarf goats and analysed. Method consisted firstly of collecting 270 blood samples from the jugular vein and of looking for anti-Anaplasma antibodies using the cELISA test. Then, 270 blood smears were made from blood taken at the level of the auricular vein of these same animals to also detect Anaplasma spp with optical microscope. Results obtained showed that 56 sera were positive to anti-Anaplasma antibodies with a seroprevalence of $20.74 \%$. Similarly, observation of the smears with microscope showed that 12 slides were infested by Anaplasma spp with prevalence of $4.44 \%$. Significant difference was observed between the two prevalence obtained according chi-square test. Moreover, the comparison between the two tests used showed a low agreement. However, Anaplasma marginale and Anaplasma centrale two species of the genus Anaplasma were identified in this study. These results will help select appropriate diagnostic methods to establish an adequate strategy for the control of Anaplasma spp.

Copy Right, IJAR, 2018,. All rights reserved.

\section{Introduction:-}

Anaplasmosis is a widespread disease in cattle, sheep and goats. It is transmitted by arthropods such as Boophilus and Rhipicephalus (De la Fuente et al., 2003; Maria and Martin, 2016). The infection is characterized by a strong hyperthermia rash accompanied by severe anemia, anorexia, weakness and weight loss (Aubry and Geale, 2011). Transmission to livestock occurs either cyclically by ticks or mechanically by biting flies (Scoles et al., 2005). Parasite undergoes a complex developmental process in the epithelial and muscular tissue of the midgut, involving the multiplication by binary division of large reticulate forms that give rise to dense bodies (Kocan, 1998). After being introduced into the mammalian bloodstream, the initial bodies of infectious Anaplasma enter erythrocytes by invagination of the cytoplasmic membrane and subsequent formation of a vacuole. Infectious forms multiply by binary division, producing initial bodies, which are frequently observed at acute stages of the disease. But the number of parasitized erythrocytes decreases as the disease becomes chronic. These parasites are responsible for a disease of variable severity whose clinical expressions are rare occurring occasionally or appearing in limited

Corresponding Author:-Oussou k. A.

Address:-Animal biology and cytology Laboratory, UFR SN, Nangui Abrogoua University, Abidian (Côte d'Ivoire). 02 BP 801 Abidian 02. 
geographical areas. This makes the diagnosis difficult and their prevalence often underestimated (Ohashi et al., 2005). They are often the cause of several weeks of inactivity, sometimes leading to considerable losses in production and fertility on farms (Sharff, 2010; Moses and Phillip, 2013).

\section{Material and methods:- Study zone}

This study is a cross-sectional study. It was conducted from December 2015 to September 2016 on goats from the Béoumi sub-prefecture in central Côte d'Ivoire, in humid West Africa, between the tropic of cancer and the equator (FAO, 2005). This sub-prefecture covers an area of $1780 \mathrm{~km}^{2}$ for 73475 inhabitants (INS, 2014). It is limited to the north by the sub-prefecture of Bodokro, to the south by the department of Sakassou, to the east by the department of Bouaké, to the west by the sub-prefectures of Kounahiri and Gohitafla (Fig. 1). Relief consists of a set of trays. Climate is of Baoulean type, characterized by a dry season and a wet season, with rainfall between 1200 and 1600 $\mathrm{mm} /$ year (FAO, 2005). Two rivers irrigate the sub-prefecture namely the Bandama River and the Kan River which is its tributary. This site was chosen because of the presence of a large number of goat farmers.

\section{Samples collection}

Study was conducted on a total of 270 dwarf goats coming from two different zones (Zone A and Zone B). These animals were divided into two groups. The first group including 135 dwarf goats were come from all the localities located at more than $15 \mathrm{~km}$ of the rivers (Zone A). This area is characterized by savannah which is covered with grass and shrubs. This herbaceous carpet is abundant during the rainy seasons but is destroyed by the fires in the dry season. The second group including also 135 goats were come from all the zones located close to the rivers Bandama and Kan between 0.5 and $1 \mathrm{~km}$ (zone B). These two rivers do not dry during the dry season; their bank promotes the development of vegetation likely to host some vectors of Anaplasma. Two types of sample were collected. The first type ( 270 blood sample) was taken out on the level of the jugular vein for the realization of the serological examinations (ELISA). The second type (270 blood samples) was taken out on the level of auricular vein for the parasitological examinations (blood Smears).

\section{Serological examination}

Test of competition ELISA (VMRD Inc. Pullman, WA, USA) was used to provide results which will give indications on the presence or not of an infection by Anaplasma spp. About 3 to $3.5 \mathrm{~mL}$ of blood was collected from the jugular vein of the dwarf goats and centrifuged at $3000 \mathrm{rpm}$ for 5 minutes to obtain the sera. These sera were tested using the cELISA kit according to the manufacturer's recommendations. The reading of the optical densities was done with a spectrophotometer set at $650 \mathrm{~nm}$. Percentage inhibition was calculated according to the following formula:

$$
\text { Percentage Inhibition }(\%)=\frac{(\text { OD of the sample })}{(\text { OD of the negative controls })} X 100
$$

Average of the negative controls must have an optical density (OD) between [0.40 and 2.1]. Average of the positive controls must have an inhibition greater than $30 \%$. Test is declared negative if the percentage inhibition is less than $30 \%$. It is positive if the percentage inhibition is greater than $30 \%$.

\section{Parasitological examination}

Blood smears were observed optical microscope to look for anaplasms starting from the criteria of morphology and morphometry. Auricular vein of the dwarf goat is pricked with a sterilized needle and then a drop of blood is collected and deposited on a sterile slide. This drop is then spread using another sterile slide. Preparation is dried and transported to the Parasitology Unit of the Central Veterinary Laboratory of Bingerville (LCVB). Once in the laboratory, the smear is fixed with methanol and stained with Giemsa (Sitotaw et al., 2014). After staining, it is dried at laboratory temperature and then observed under optical microscope at the x100 objective and immersion for the detection of Anaplasma spp. Identification keys used are those of Radostits et al. (2000) and Kocan et al, (2010). According to these authors, anaplasms appear in the form of intracellular points, most often unique, of 0.4 to $0.8 \mu \mathrm{m}$, generally located on the periphery of the cytoplasm (Anaplasma marginale) or in central position (Anaplasma centrale). 


\section{Expression of results and statistical treatments}

Excel was used to record data collected and to prevalence calculate. Prevalence was determined according to the tests used and the sampling zones according to the following formula:

$$
\text { Prevalence of Anaplasma sp (\%) }=\frac{(\text { Number of Anaplasma sp })}{(\text { Number of samples tested })} \times 100
$$

Khi 2 test of the SPSS software made it possible to statistically compare the different proportions obtained in order to determine a significant difference at the 5\% threshold. Concordance was assessed between cELISA and blood smear tests using the kappa (K) coefficient of the Ancelle (2011) formula.

$K=\frac{C c-C a}{1-C a} ; C c=\frac{\text { Number of concordant examinations }}{\text { Number of compared examinations }} ; C a=\frac{t_{1} n_{1}+t_{2} n_{2}+. .+t_{i} n_{i}}{N^{2}}$

$\mathrm{n}=$ number of samples tested

$\mathrm{N}=$ total number of samples tested

$\mathrm{t}=$ test.

For each value of the kappa coefficient $(\mathrm{K})$, a quite specific interpretation is given (Table 1).

\section{Results and discussion:-}

\section{Obtained proportions}

Tests serologic revealed the presence of anti-Anaplasma antibody in 56 serums on a total of 270 serums tested, that is to say a seroprevalence of $20.74 \%$ of which $33.33 \%$ at the edge of the watercourse and $8.15 \%$ far away streams (Table 2). The observation of blood smears with optical microscope made it possible to detect 12 positive slides by Anaplasma spp only at the edge of watercourses with prevalence of $4.44 \%$. Moreover two species; Anaplasma marginale and Anaplasma centrale have been identified in blood smears. However, serological examinations yielded more positive samples than parasitological examinations. This difference is significant according to the chisquare test at the threshold of $5 \%($ Khi $2=32.572, \mathrm{ddl}=1, \mathrm{P}=0.001)$.

Difference observed between the two diagnostic methods could be explained by the fact that the diagnostic method using the cELISA technique is more sensitive than the method of diagnosis by observation of the blood films under the light microscope. The infection is visible under a microscope during the period when parasitaemia is high. After recovering from the initial infection, most animals remain latently infected for life. However, except in some cases of recrudescence, cannot be easily detected in blood smears because of low parasitaemia. Then the morphology of the anaplasms is difficult to distinguish if the smears are not well prepared. These anaplasms can be easily confused with extraneous matter such as artifacts, bodies of Howel-Joly or Heinz (Noaman et al., 2009) that disorient the diagnosis which explains the low prevalence obtained with blood smears $(4.44 \%)$. However, the cELISA tests have been developed with the aim of revealing both past infections and current infections. However, a positive cELISA test does not necessarily reflect the existence of a current infection (Buling et al., 2007), chronic or even cured infected could be detected, hence the explanation of the high prevalence obtained with the cELISA tests (20.74\%). These same observations were made by Terkawi et al. (2011). These authors have shown that the serological diagnosis which is a recent technological innovation is much more sensitive than the traditional diagnosis by blood smear observations.

\section{Prevalence of Anaplasma spp according to the area}

Of the 270 blood samples tested in remote areas of rivers, only 11 were cELISA positive, representing a seroprevalence of $8.15 \%$. No blood smears were detected positive for Anaplasma spp in remote areas of streams (Table 3). In contrast, the 270 blood samples analyzed near streams revealed the presence of anti-Anaplasma antibodies in 45 sera by the cELISA method with a seroprevalence of $33.58 \%$. The observation of the smears showed the existence of Anaplasma including Anaplasma marginale and Anaplasma centrale in 12 blood smears, a prevalence of $8.89 \%$ (Table 3). A significant difference was observed between these two prevalence determined along watercourses according to the chi-square test $(\mathrm{Khi} 2=24.218, \mathrm{ddl}=1, \mathrm{P}=0.001)$.

Observation of the smears made it possible to detect two species in this study: Anaplasma marginale and Anaplasma centrale. This result would be related to this technique which directly looks for parasites in the blood whereas the 
cELISA (VMRD Inc. test, Pullman, WA, USA) used is directed against the antibodies of several parasites at a time. Although the infecting species may sometimes be identified using antigens of the homologous or heterologous species, equivocal results are often obtained according to Jenevaldo et al. (2013). Seroprevalence of $33.33 \%$ observed in the areas bordering rivers is higher than that of $8.15 \%$ observed in the remote areas of rivers. In fact, 56 samples out of 270 were detected positive in the cELISA test, 45 of which came from areas bordering rivers and 11 from remote areas of rivers. . Most dwarf goats infested with Anaplasma spp come from areas along the Bandama River and Kan River. The surroundings of these rivers represent a microclimate in which moisture is maintained for the survival of certain vectors responsible for anaplasmosis (Urdaz-Rodriguez et al., 2012). This would explain the many cases of goats infested in these places. These results are in accordance with the observations of Memeteau et al. (1998) who reported that the risk of infestation is higher in the presence of thick vegetation and, above all, natural, uncultivated vegetation. This has been confirmed by Estrada Pena (2001). This author has stated that ticks responsible for anaplasmosis have a preference for areas around streams. However, some infested goats have been detected far from streams where the climate is dry. It is rightly that Estrada Pena et al. (2004) will say that these cases are due to some vector species that are better adapted to the areas where hard-leafed and thick-cuticle plants predominate as habitat for their survival and multiplication. But this difference would also be related to bush fires that are almost common in remote areas of rivers. When living conditions are unfavourable in an area, the vectors move away, adapt by remaining in a slower state of life, or die (Guigen and Degeilh, 2001). It is therefore not impossible for vectors to disappear as a result of environmental changes as predicted by Retolph (2001). Thus, the risk of being bitten may have decreased: this explains the low prevalence observed in areas far from watercourses compared to areas close to rivers (Keita, 2007).

\section{Concordance of the two diagnostic tests}

Twelve (12) samples were tested positive for both smear and ELISA. Similarly, forty-four (44) samples were also tested negative for blood smears and positive for ELISA. No sample was observed positive for smear and ELISAnegative, however, two hundred and fourteen (214) samples were negative for smear and negative for ELISA (Table 4). The observed concordance $(\mathrm{Cc})$ is 0.83 , and that expected $(\mathrm{Ca})$ is 0.76 . The Kappa coefficient $(\mathrm{K})$ obtained is: $\mathrm{K}$ $=0.30$. The value of $\mathrm{K}$, obtained is greater than 0.21 and less than 0.40 in the reading grid of the Kappa coefficient (K) which corresponds to a weak agreement.

A low agreement $(\mathrm{K}=0.30)$ was obtained at the agreement between the blood smear tests and the cELISA tests for the detection of Anaplasma spp. This agreement seems normal since smear tests, which have always been used, are very insensitive to the new cELISA technical innovations. However the result found in this study is different from that found by Badolo et al. (2014). These authors, according to a similar study conducted in Burkina Faso on the contribution to the epidemiological study of anaplasmosis obtained an almost perfect agreement (0.98) between the smear test and the cELISA test.

\section{Conclusion:-}

Comparison of the two bioassays to assess Anaplasma spp in dwarf goat blood samples showed that the cELISA test is more sensitive than blood smears. This test detected the presence of numerous anti-Anaplasma antibodies compared to the anaplasms observed in the blood smears. However, the two biological tests used have certain limits. These limits were evaluated according to their specific nature to distinguish the species of the same genus with the cELISA kit used on the one hand. Cross reactions make it difficult to accurately diagnose the bacterium involved. Then on the other hand their property to react to low bacterial loads with smears. It is difficult to observe anaplasms when the parasitemia is weak.

Table 1:-Kappa coefficient interpretation grid (Landis and Koch, 1977)

\begin{tabular}{|c|c|c|c|c|c|c|}
\hline $\begin{array}{l}\text { Coefficient } \\
\text { Kappa(K) }\end{array}$ & $<0$ & {$[0$ et 0,20] } & {$[0,21$ et 0,40$]$} & {$[0,41$ et 0,60$]$} & {$[0,61$ et 0,80$]$} & {$[0,81$ et 1] } \\
\hline $\begin{array}{c}\text { Interpretation } \\
\text { Landis and Koch, } \\
(1977)\end{array}$ & Disagree & $\begin{array}{c}\text { Very low } \\
\text { agreement }\end{array}$ & $\begin{array}{c}\text { Low } \\
\text { agreement }\end{array}$ & $\begin{array}{c}\text { Moderate } \\
\text { agreement }\end{array}$ & $\begin{array}{c}\text { Strong } \\
\text { agreement }\end{array}$ & $\begin{array}{c}\text { Near perfect } \\
\text { agreement }\end{array}$ \\
\hline
\end{tabular}


Table 2:-Results of biological examinations

\begin{tabular}{|c|c|c|c|c|c|}
\hline & Methods used & Positive samples (n) & Negative samples (n) & $\begin{array}{c}\text { Samples tested (n) } \\
\begin{array}{c}\text { Prevalences } \\
(\%)\end{array}\end{array}$ \\
\hline \multirow{2}{*}{ Anaplasma spp } & cELISA & 56 & 214 & 270 & $20.74^{\mathrm{a}}$ \\
\cline { 2 - 6 } & Blood smears & 12 & 258 & 270 & $4.44^{\mathrm{b}}$ \\
\hline
\end{tabular}

Exponents $\mathrm{a}$ and $\mathrm{b}$ in the same column indicate a significant difference between prevalences of Anaplasma spp based on the two diagnostic tests for $\mathrm{p}<0.05$.

Table 3:-Prevalence in different areas

\begin{tabular}{|c|c|c|c|c|c|}
\hline & $\begin{array}{c}\text { Methods } \\
\text { used }\end{array}$ & $\begin{array}{c}\text { Positive samples } \\
(\mathrm{n})\end{array}$ & $\begin{array}{c}\text { Negative samples } \\
(\mathrm{n})\end{array}$ & $\begin{array}{c}\text { Samples tested } \\
(\mathrm{n})\end{array}$ & $\begin{array}{c}\text { Prevalences } \\
(\%)\end{array}$ \\
\hline \multirow{2}{*}{$\begin{array}{c}\text { Remote areas of } \\
\text { streams }\end{array}$} & cELISA & 11 & 124 & 135 & 8.15 \\
\cline { 2 - 6 } & $\begin{array}{c}\text { Blood } \\
\text { smears }\end{array}$ & 00 & 135 & 135 & 0 \\
\hline Areas near streams & cELISA & 45 & 90 & 135 & $3.33^{\mathrm{a}}$ \\
\cline { 2 - 6 } & $\begin{array}{c}\text { Blood } \\
\text { smears }\end{array}$ & 12 & 123 & 135 \\
\hline
\end{tabular}

Exponents $\mathrm{a}$ and $\mathrm{b}$ in the same column indicate a significant difference between prevalences of Anaplasma spp based on the two diagnostic tests for $\mathrm{p}<0.05$.

Table 4:-Data of the concordance data

\begin{tabular}{|c|c|c|c|}
\hline & $\begin{array}{c}\text { Positive samples } \\
\text { (ELISA test) }\end{array}$ & $\begin{array}{c}\text { Negative samples } \\
\text { (ELISA test) }\end{array}$ & Total (n) \\
\hline $\begin{array}{c}\text { Positive samples } \\
\text { (Blood smear) }\end{array}$ & 12 & 44 & 56 \\
\hline $\begin{array}{c}\text { Negative samples } \\
\text { (Blood smears) }\end{array}$ & 0 & 214 & 214 \\
\hline Total (n) & 12 & 258 & 270 \\
\hline
\end{tabular}

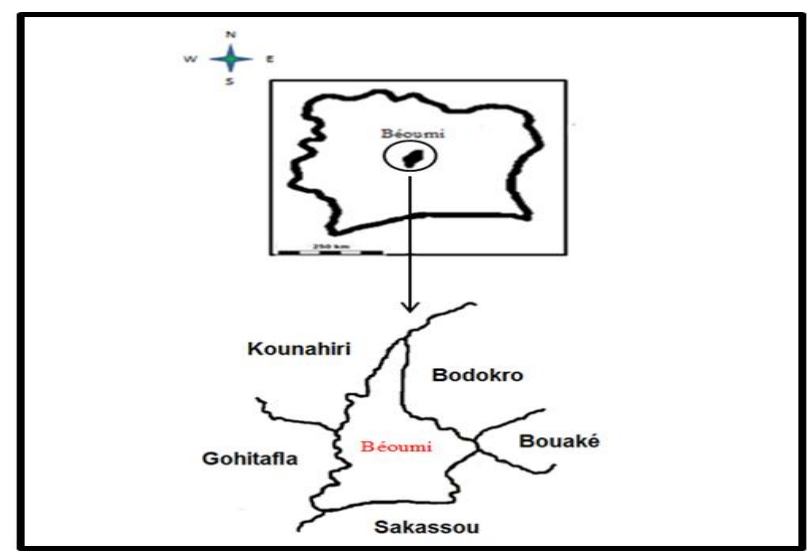

\section{References:-}

Fig. 1:-Map of the study area (Maphill, 2011)

1. Ancelle T. 2011. Statistique épidémiologie. Collection Sciences fondamentales Edition, Maloine (3) Paris France, 360.

2. Aubry P, Geale DW. 2011. Transboundary and emerging diseases. A review of bovine anaplasmosis 58, 1-30.

3. Badolo H. 2014. Contribution à l'étude épidémiologique des anaplasmoses et des babésioses suite à l'introduction récente de la tique Rhipicephalus (Boophilus) microplus (Canestrini, 1888) dans le Sud-Ouest du Burkina Faso. Master de Productions et Industries Animales, Université Polytechnique de Bobo-Dioulasso (UPB), 62. 
4. Buling A, Criado-Fomelio A, Asenzo G, Benitez D, Barba-Carretero JC, FlorinChristensen M. $2007 . \quad$ A quantitative PCR assay for the detection and quantification of Babesia bovis et Babesia bigemina. Veterinary Parasitology 147, 16-25.

5. De la Fuente J, Golsteyn Thomas JE, Van Den Bussche AR., Hamilton GR, Tanaka EE, Druha ES, Kocan MK. 2003. Characterization of Anaplasma marginale isolated from North American bison. Applied and Environmental Microbiology 69, 5001-5005.

6. Estrada-Pena A. 2001. Distribution, abundance, and habitat preferences of Ixodes ricinus (Acari: Ixodidae) in northern Spain. Journal of Medicine Entomology 38, 361-70.

7. Estrada-Pena A, Martinez JM, Sanchez AC, Quilez J, Del Cacho E. 2004. Phenology of the tick, Ixodes ricinus, in its southern distribution range (central Spain). Medecine of Veterinary Entomology 18, 387-397.

8. FAO. 2005. (Organisation des Nation Unies pour l'Alimentation et l'agriculture). L'irrigation en Afrique en chiffres - Enquête AQUASTAT, 10.

9. Guigen C, Degeilh B. 2001. Les tiques d'intérêt médical : rôle vecteur et diagnose de laboratoire. Revue Française des Laboratoires 338, 49-57.

10. INS. 2014: Rapport d'exécution et présentation des principaux résultats du Recensement General de la population et de l'Habitat (RGPH, 2014), 49.

11. Jenevaldo BDS, Etré MR, Henrique da Fonseca A, Tâvora de Albuquerque Lopes C, Henrique da Silva Lima D, Tavares de Etrade SJ, Oliveira CMC, Barbosa ID. 2013. Molecular and serological prevalence of Babesia bovis and Babesia bigemina in water buffaloes in the north region of Brazil. Veterinary Parasitology 197, 678-681.

12. Kocan KM, De la Fuente J, Step DL, Blouin EF, Coetzee JF, Simpson KM, Genova SG, Boileau MJ. 2010. Current challenges of the management and epidemiology of bovine anaplasmosis. The Bovine Practitioner 44 , 93-102.

13. Kocan KM, Stiller D, Goff WL, Edwards WE, Wickwire KB, Stick RW, Yellin TN, Ewing SA, Palmer GH, Barron SJ, Hair JA, McGuire TC. 1998. The developmental cycle of Anaplasma marginale in Dermacentor spp. In: Proceedings of the 8th National Veterinary Hemoparasite Disease Conference, St. Louis, 149-160.

14. Landis JR, Koch GG. 1977. The measurement of observer agreement for categorical data. Biometrics 33, 159174.

15. Maphill, 2011. Cartographie de Béoumi. www.maphill.com/search/. Consulté le 15 janvier 2017.

16. Maria EK, Martin OA. 2016. Babesia species in questing Ixodes ricinus, Sweden. Ticks and Tickborne Diseases 7, 10-12.

17. Memeteau S, Seegers H, Jolivet F, L'Hostis M. 1998. Assessment of the risk of infestation of pastures by Ixodes ricinus due to their phyto-ecological characteristics. Veterinary Research, 29, 487-496.

18. Moses SM, Phillip SM. 2013. Molecular diagnosis and phylogenetic analysis of Babesia bigemina and Babesia bovis hemoparasites from cattle in South Africa. BMC Veterinary Research 9, 154.

19. Noaman V, Shayan P, Amininia N. 2009. Molecular Diagnostic of Anaplasma marginale in Carrier Cattle, Iranian Journal Parasitology, 4, 26-33.

20. Ohashi N, Inayoshi M, Kitamura K, Kawamori F, Kawaguchi D, Nishimura Y. 2005. Anaplasma phagocytophillum-infected ticks, Japan. Emerging Infectious Diseases, 11, 1780-1783.

21. Radostits OM, Gay CC, Blood DC, Hinchcliff KW. 2007. Veterinary Medicine: A textbook of the diseases of cattle, horses, sheep, pigs and goats. (9 ${ }^{\text {th }}$ edition).W.B. Saunders Compagny Ltd (Ed), London, 486-489.

22. Retolph TF. 2007. Rôle de l'élevage dans la nutrition et la santé humaines pour la réduction de la pauvreté dans les pays en développement. Journal of Animal Science 85, 2788-2800.

23. Scoles GA, Broce A, Lysyk T, Palmer G. 2005. Relative Efficiency of Biological Transmission of Anaplasma marginale (Rickettsiales: Anaplasmataceae) by Dermacentor etersoni (Acari: Ixodidae) Compared with Mechanical Transmission by Stomoxys calcitrans (Diptera: Muscidae), Journal of Medical Entomology 42, 668-675.

24. Sitotaw T, Regassa F, Zeru F, Kahsay, AG. 2014. Epidemiological significance of major hemoparasites of ruminants in and around Debre-Zeit, Central Ethiopia. Journal of Parasitology Vector Biological 6, 16-22.

25. Sharff RL. 2010. Economic burden from health losses due to foodborne illness in the United States. Journal of food protection 75, 123-131.

26. Terkawi MA, Huyen NX, Shinuo C, Inpankaew T, Maklon K, Aboulaila M, Ueno A, Goo YK, Yokoyama N, Jittapalapong S, Xuan X. 2011. Molecular and serological prevalence of Babesia bovis and Babesia bigemina in water buffaloes in the northeast region offhailet. Veterinary Parasitology 178, 201- 220.

27. Urdaz-Rodriguez J, Fosgate G, Alleman AR., Rae O, Donovan A, Binford M, Zaragoza A, Melendez P. 2012. Association between ecological factors and the presence of Rhipicephalus (Boophilus) microplus larvae in Puerto Rico. Experimental applied acarology 58, 145-157. 